\title{
Potential of Tsuga spp. from Western North America and Asia as Replacements for Eastern Hemlock (Tsuga canadensis)
}

\author{
Paul A. Weston and Richard W. Harper
}

\begin{abstract}
Hemlock woolly adelgid (Adelges tsugae) has had a devastating impact on Tsuga canadensis and T. caroliniana in forests and managed landscapes in the eastern United States. Species of Tsuga from the western United States and Asia are reported to be tolerant or resistant to A. tsugae. We established plots containing T. canadensis, T. caroliniana, T. chinensis, T. diversifolia, T. heterophylla, T. mertensiana, and T. sieboldii in Katonah, New York, U.S., an area with high populations of A. tsugae, and monitored tree growth and infestation by adelgids over a 4-year period. Growth and survival of the hemlock species varied widely, the most vigorous species being $T$. canadensis and $T$. chinensis. Susceptibility to the adelgid also varied widely among species; some species (particularly T. canadensis) became readily infested, whereas others (e.g., T. chinensis) were apparently entirely resistant. Given the ability of T. chinensis to thrive in the climate of southeastern New York State and its apparent resistance to hemlock woolly adelgid, this species might be an appropriate replacement species, especially in managed landscapes.
\end{abstract}

Key Words. Elongate hemlock scale; hemlock; hemlock woolly adelgid; host resistance; Tsuga.

Hemlock woolly adelgid (HWA), Adelges tsugae, is a tiny sap-feeding insect endemic to Asia and introduced to the eastern United States in the 1950s (Gouger 1971). Despite its small size, the insect is capable of killing mature hemlocks within several years after an infestation has begun (McClure 1991). It has caused widespread destruction of native hemlocks (Tsuga canadensis and T. caroliniana) in forests and landscapes in the eastern United States from Georgia to Maine, principally in the Appalachian Mountains eastward to the Atlantic coast (Ward et al. 2004). Species of hemlock from the western United States (e.g., T. heterophylla and T. mertensiana) are tolerant of hemlock woolly adelgid because they are often heavily infested but show no signs of injury (McClure 1992). T. chinensis, native to China, is resistant (resistance mechanism unspecified) (Bentz et al. 2002; Del Tredici and Kitajima 2004; Havill and Montgomery 2008). Species of Tsuga from Japan (T. diversifolia and T. siedboldii) show varying degrees of susceptibility to HWA; T. diversifolia is reportedly a poor host for HWA, supporting only limited populations (McClure 1992; Bentz et al. 2002), whereas T. sieboldii has been found to vary in infestation from uninfested to severely infested (Bentz et al. 2002). Thus, species of Tsuga from the western United States and Asia are worthy of investigation as potential replacements for T. canadensis and T. caroliniana.

A major consideration determining the suitability of a species as a replacement for susceptible trees is the ability of the alien species to tolerate the climatic conditions in the new location. Bentz et al. (2002) suggest that species of Tsuga from the western United States are poorly adapted to the climate in the East (but provide no data). Del Tredici and Kitajima (2004) report that $T$. chinensis, in addition to being resistant to HWA, performed very well in the Boston, Massachusetts, area, and was hardy to USDA Hardiness Zone 6. No data have been published on the ability of hemlocks from Japan (T. diversifolia and
T. sieboldii) to tolerate the climatic conditions of the northeastern United States.

An interesting observation on HWA biology was reported by McClure (1991), who found that nitrogen-based fertilizers had highly stimulatory effects on HWA infesting $T$. canadensis. HWA nymphal survival was twice as high on fertilized trees versus unfertilized controls, and resulting adults produced twice as many eggs each as compared with adults from the control trees. In addition, fertilized trees had five times more adelgids and produced $25 \%$ less new growth than unfertilized trees. It is not known if nitrogen fertilization has any impact on the susceptibility of other species of Tsuga to HWA.

The main objectives of this study were threefold: 1) to determine the susceptibility to HWA of Tsuga spp. from the western United States and Asia in the eastern United States (Hudson Valley Region of New York); 2) to document the ability of these species to tolerate the climate in the Hudson Valley; and 3) to determine the impact, if any, of nitrogen fertilization on susceptibility of these hemlock species to HWA. In addition, we sought to catalog the species of insects (both pests and natural enemies) on the test trees.

\section{MATERIAL AND METHODS}

\section{Research Site}

The experimental plots were established within the fenced portion of Lasdon Park and Arboretum in Katonah, New York, U.S. The test site is within USDA Hardiness Zone 6b; typical monthly temperature extremes and precipitation are shown in Table 1. The fencing was essential for protecting the young trees from herbivory by white-tailed deer, which are abundant in the area. Three plots were established within the confines of the arboretum, spatially separated and situated in sites varying in topography 
Table 1. Average monthly temperature extremes and precipitation for Scarsdale, NY, approximately $20 \mathrm{mi}$ from the research plots in Katonah, NY.

\begin{tabular}{|c|c|c|c|c|c|c|}
\hline \multirow[b]{2}{*}{ Month } & \multicolumn{2}{|c|}{$\begin{array}{l}\text { Minimum } \\
\text { temperature }\end{array}$} & \multicolumn{2}{|c|}{$\begin{array}{l}\text { Maximum } \\
\text { temperature }\end{array}$} & \multicolumn{2}{|c|}{ Precipitation } \\
\hline & ${ }^{\circ} \mathrm{C}$ & ${ }^{\circ} \mathrm{F}$ & ${ }^{\circ} \mathrm{C}$ & ${ }^{\circ} \mathrm{F}$ & $\mathrm{mm}$ & in \\
\hline January & -6.8 & 19.8 & 3.1 & 37.6 & 87.9 & 3.5 \\
\hline February & -5.5 & 22.1 & 4.9 & 40.8 & 73 & 2.9 \\
\hline March & -1.4 & 29.5 & 10.1 & 50.2 & 106.6 & 4.2 \\
\hline April & 3.6 & 38.5 & 16.5 & 61.7 & 101 & 4 \\
\hline May & 8.7 & 47.7 & 22.7 & 72.9 & 101.1 & 4 \\
\hline June & 13.7 & 56.7 & 27.2 & 81 & 91.2 & 3.6 \\
\hline July & 16.9 & 62.4 & 29.8 & 85.6 & 101 & 4 \\
\hline August & 16.3 & 61.3 & 28.7 & 83.7 & 119.5 & 4.7 \\
\hline September & 12.1 & 53.8 & 24.5 & 76.1 & 111.6 & 4.4 \\
\hline October & 6 & 42.8 & 18.6 & 65.5 & 88 & 3.5 \\
\hline November & 1.8 & 35.2 & 12.3 & 54.1 & 103.9 & 4.1 \\
\hline December & -3.6 & 25.5 & 5.6 & 42.1 & 98.6 & 3.9 \\
\hline
\end{tabular}

${ }^{2}$ Data averaged from 1961 to 1990 . Source: www.worldclimate.com.

and exposure to solar radiation (Figure 1). Plot 1 ("Front Gate") was situated on the northern border of the fenced area, slightly sloping to the north with full exposure to the sun on all but the western side and southwest corner. Plot 2 ("Magnolia Garden") was centrally located on a nearly level site bordered on the south and west by tall conifers. Plot 3 ("Hemlock Hedge") was situated in a low-lying clearing in a largely wooded area populated by deciduous hardwoods on all sides except the north, which was devoid of trees. Plot 2 was roughly equidistant between the other two plots, approximately $250 \mathrm{~m}(825 \mathrm{ft})$ away from each.

Each plot was roughly $12.2 \mathrm{~m} \times 13.7 \mathrm{~m}(40.3 \mathrm{ft} \times 45.2 \mathrm{ft})$ in size and had six rows of trees $12.2 \mathrm{~m}(40.3 \mathrm{ft}$ ) in length (spacing within and between rows was approximately $2 \mathrm{~m}[6.6 \mathrm{ft}]$ ). Each row was intended to have one of each of the seven test species plus a second representative of $T$. canadensis, which was to serve as a negative control (after pesticide application) for that species after adelgid establishment; the order of trees within a row was

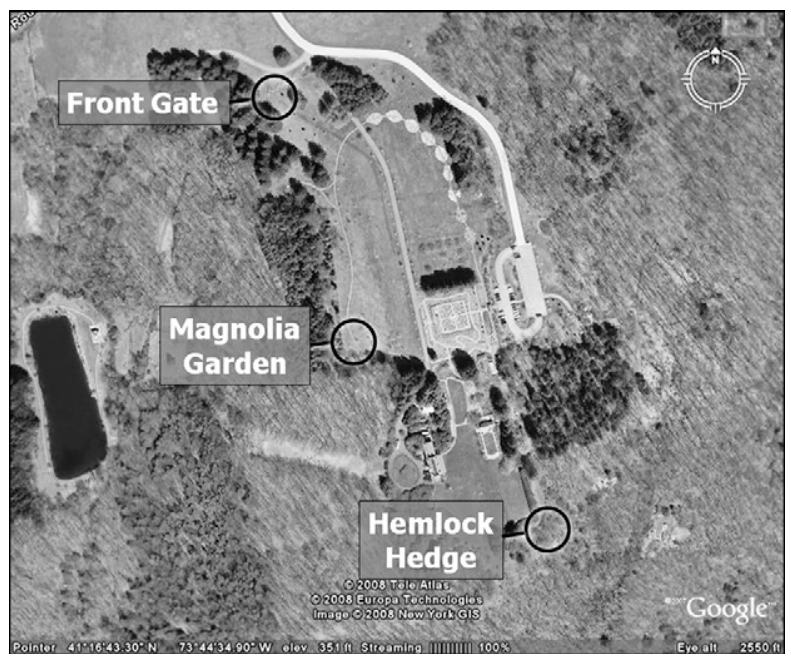

Figure 1. Layout of plots at Lasdon Park and Arboretum, Katonah, New York, U.S. Distance from top of figure to bottom represents approximately $500 \mathrm{~m}$ (1650 ft). determined at random. Because seven specimens of T. heterophylla and one T. caroliniana died before they could be set out in the plots, some rows were lacking a complete complement of trees (the remaining specimens of T. heterophylla were distributed as evenly as possible among plots). The plots were further subdivided into two subplots, one fertilized and one unfertilized (three rows of trees in each half). Fertilizer $(30 \mathrm{~N}-10 \mathrm{P}-10 \mathrm{~K}$ in October 2003, 10N-6P-4K in May 2004, and 4N-6P-4K thereafter) was applied at the rate of $7.3 \mathrm{~kg} \mathrm{~N} / 1000 \mathrm{~m}^{2}(1.5 \mathrm{lb} \mathrm{N} / 1000$ $\mathrm{ft}^{2}$ ) in spring and fall to the subplots designated as the fertilizer treatment. This rate was based on recommendations from Ohio State University Extension (Rose and Smith 1996). For the first 3 years, trees were mulched with a mixed woodchip mulch (composition unspecified) each spring for weed management and moisture retention; the area between the trees was mowed as needed during the summer; after that, the entire area within each plot was mulched yearly.

\section{Plant Material}

Seven species of Tsuga were evaluated (Table 2). two from the eastern United States (T. canadensis and T. caroliniana), two from the western United States (T. heterophylla and T. mertensiana), two from Japan (T. diversifolia and T. sieboldii), and one from China (T. chinensis). Trees were purchased from several sources in the western United States. Unfortunately, trees were not of uniform size when starting the experiment (Table 2).

To increase the probability of infestation by A. tsugae, we inoculated test trees with infested hemlock twigs in spring of 2005 and 2006. Twig sections of T. canadensis heavily infested with egg masses of A. tsugae were attached to a branch of test trees with twist ties in April or May (branches had been collected in March, before egg hatch, and had been stored in a refrigerator at approximately $5^{\circ} \mathrm{C}$ until being used for inoculation). As eggs hatched, we expected that crawlers would migrate from the source twig to the host tree. On larger trees, the branch chosen for inoculation was at midheight.

Trees were evaluated for health and pest establishment in spring and fall of each year. Data collected included tree height (measured to the nearest inch), a visual estimate of tree vigor (on a scale of 0 to 5 with higher numbers corresponding to better condition), and the presence or absence of hemlock woolly

Table 2. Height, survivorship, and vigor of test hemlock species after 4 years. ${ }^{2}$

\begin{tabular}{llllll}
\hline & & & & \multicolumn{2}{c}{ Tree height $(\mathrm{cm})$} \\
\cline { 5 - 7 } Species & $n$ & Survivorship $^{\mathrm{y}}$ & Vigor $^{\mathrm{x}}$ & Initial & After 4 years \\
\hline T. canadensis & 36 & $83.3 \pm 8.6 \mathrm{ab}$ & $4.2 \pm 0.1 \mathrm{a}$ & $124.9 \pm 3.4$ & $325.5 \pm 12.4$ \\
T. caroliniana & 18 & $33.3 \pm 12.2 \mathrm{c}$ & $3.7 \pm 0.3 \mathrm{ab}$ & $23.5 \pm 1.2$ & $34.0 \pm 4.6$ \\
T. heterophylla & 11 & $75.0 \pm 17.1 \mathrm{ab}$ & $3.4 \pm 0.2 \mathrm{bc}$ & $62.0 \pm 4.7$ & $204.4 \pm 44.2$ \\
T. mertensiana & 18 & $44.4 \pm 16.5 \mathrm{bc}$ & $3.0 \pm 0.5 \mathrm{c}$ & $33.9 \pm 0.8$ & $30.7 \pm 5.6$ \\
T. chinensis & 18 & $94.4 \pm 5.5 \mathrm{a}$ & $4.2 \pm 0.1 \mathrm{a}$ & $89.8 \pm 3.2$ & $239.6 \pm 9.9$ \\
T. diversifolia & 18 & $38.9 \pm 10.2 \mathrm{c}$ & $4.1 \pm 0.2 \mathrm{a}$ & $16.1 \pm 0.7$ & $31.7 \pm 6.6$ \\
T. sieboldii & 18 & $44.4 \pm 18.6 \mathrm{bc}$ & $3.6 \pm 0.3 \mathrm{ab}$ & $16.7 \pm 0.9$ & $32.8 \pm 6.8$ \\
\hline
\end{tabular}

${ }^{\mathrm{z}}$ Values are means $\pm \mathrm{SE}$ of treatment mean.

'Values followed by the same letter are not statistically different as determined by split-plot analysis of variance followed by least significant difference test. ${ }^{x}$ Vigor was measured during spring of Year 5. Values followed by the same letter are not statistically different as determined by split-plot analysis of variance followed by least significant difference test. 
Table 3. Percent increase in height of test species during the 4 years of the project. ${ }^{2}$

\begin{tabular}{lcc}
\hline & \multicolumn{2}{c}{ Percent increase in height } \\
\cline { 2 - 3 } Species & Unfertilized & Fertilized $^{y}$ \\
\hline T. canadensis & $165.2 \pm 10.0$ & $162.0 \pm 13.3$ \\
T. caroliniana & $2.8 \pm 38.5$ & $41.7 \pm 9.7$ \\
T. heterophylla & $120.3 \pm 31.2$ & $254.8 \pm 90.8^{*}$ \\
T. mertensiana & $-18.4 \pm 6.5$ & $16.7 \pm 73.9^{*}$ \\
T. chinensis & $162.6 \pm 16.1$ & $174.3 \pm 18.9^{*}$ \\
T. diversifolia & $57.4 \pm 57.1$ & $176.2 \pm 76.5$ \\
T. sieboldii & $136.3 \pm 55.3$ & $25.0 \pm 18.4^{*}$ \\
\hline
\end{tabular}

${ }^{2}$ Note the species $\times$ fertilizer interaction. Values are means \pm SE of treatment mean.

${ }^{y}$ Asterisk $(*)$ indicates significant difference between fertilizer treatments for individual species at $P=0.05$.

adelgid and elongate hemlock scale (Fiorinia externa), a more recent pest problem of hemlocks apparently associated with the presence of HWA. The visual rating incorporated needle color, needle loss, and overall appearance as indicators of tree vigor.

\section{Data Analysis}

Tree vigor and pest infestation were analyzed with split-plot analysis of variance (ANOVA) with fertilization as the subplot treatment. Because survivorship of the test species was measured on a subplot basis rather than on a per-tree basis, this variable could not be analyzed with split-plot ANOVA. Instead, survivorship was analyzed with factorial ANOVA with tree species, fertilizer treatment, and their interaction as the factors after transforming the data with the arcsine transformation. The association between presence of hemlock woolly adelgid and elongate hemlock scale was tested with $\chi^{2}$ contingency tables. The presence of remaining arthropods on the test trees was tested with randomized complete block ANOVA.

\section{RESULTS AND DISCUSSION}

The test species varied widely in their survivorship, vigor, and growth measured after 4 years (Table 2). Not surprisingly, T. canadensis had the highest survivorship and vigor of the North American species included in the study. Of the Asian species, T. chinensis was most similar to T. canadensis; its survivorship and vigor were very comparable to that of $T$. canadensis, indicating that it was well suited to the climate in the study area. In general, vigor was higher in spring except for the western North American species (Figure 2). although the overall effect of season was not significant $(F=2.4 ; P=0.068$; df $=1,21)$. An exception was $T$. heterophylla, which had higher vigor ratings in the fall than in the spring $(F=3.3 ; P=0.018$; $\mathrm{df}=6,21)$. This species apparently sustained cold damage because the needles, especially those on branches more than $50 \mathrm{~cm}$ (20 in) above the ground and presumably not protected by snow cover, were noticeably browned in spring. By fall, however, the specimens of T. heterophylla looked as healthy as those of the most vigorous species. Specimens of T. mertensiana looked equally poor in fall and spring, consistently lower than all other test species.

Judging differences in growth among the species is complicated because the starting heights were quite different, so the percent increase in growth over 4 years is more informative.

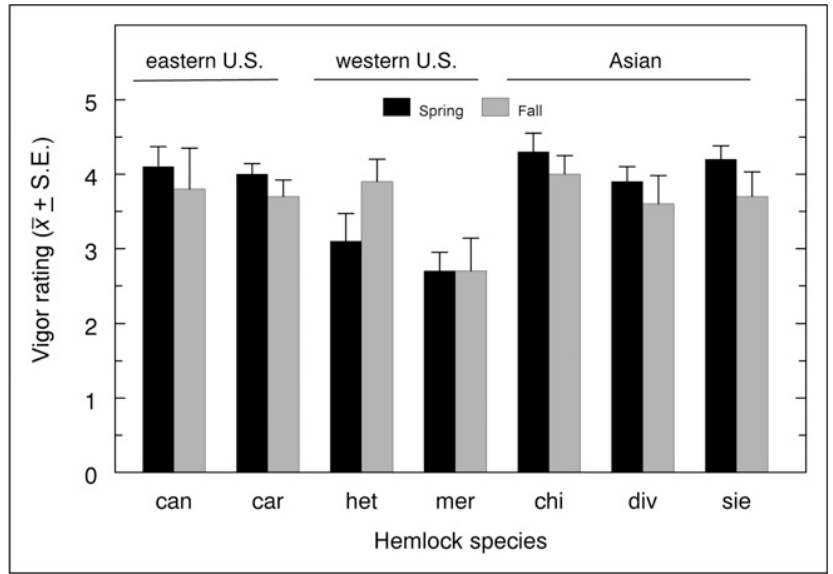

Figure 2. Vigor ratings for the seven test species of Tsuga during fall and spring averaged over the 4 years of the study. Heights of the bars indicate average vigor ration on a 0 to 5 scale, higher numbers corresponding to higher vigor ratings. can $=T$. canadensis; car $=T$. caroliniana; het $=T$. heterophylla; mer $=T$. mertensiana; chi $=T$. chinensis; div = T. diversifolia; sie $=T$. sieboldii.

Percent growth varied significantly among species $(F=11.2 ; P$ $<0.0001$; df $=6,65)$. Although the overall effect of fertilizer on percent growth was not significant $(F=7.4 ; P=0.113 ; \mathrm{df}=1,2)$, the interaction between species and fertilizer was significant $(F$ $=3.2 ; P=0.0085 ; \mathrm{df}=6,65)$ (Table 3 ). Growth of $T$. canadensis was virtually identical with and without fertilizer, but the remaining species (except $T$. sieboldii) showed varying degrees of growth stimulation in the fertilizer treatment. Oddly, the growth of T. sieboldii was actually lower in the fertilized plots.

Infestation by hemlock woolly adelgid varied greatly among species $(F=41.9 ; P<0.0001 ; \mathrm{df}=6,65)$. Like with tree growth, the overall effect of fertilizer was not significant $(F=3.2 ; P=0.21$; $\mathrm{df}=1,2)$, but the interaction between tree species and fertilizer treatment was significant $(F=2.53 ; P=0.029 ; \mathrm{df}=6,65)$. Infestation of $T$. canadensis was uniformly high in both fertilizer treatments; in unfertilized plots, $87.5 \% \pm 8.5 \%$ of trees were infested versus $92.9 \% \pm 7.1 \%$ in fertilized plots. $T$. caroliniana showed a high rate of infestation in the fertilized plots $(75 \% \pm 25 \%)$ but was uninfested in unfertilized plots. The small sample size for this species, however, rendered this result less than robust (two trees survived in the unfertilized plots and four in the fertilized plots). The only other species to exhibit signs of adelgid infestation was T. heterophylla, for which one of four trees $(25 \% \pm 25 \%)$ was infested in the unfertilized plots and none in the fertilized plots. The remaining species were free of adelgid infestation as of Spring 2008.

Elongate hemlock scale also showed variability in infestation rate among test species $(F=3.2 ; P=0.0087$; df $=6,65)$, but infestation was not influenced by fertilizer $(F=0.0 ; P=0.99$; df $=1,2)$ or its interaction with species $(F=1.6 ; P=0.160 ; \mathrm{df}=6$, 65). Overall rates of infestation by elongate hemlock scale were rather high, ranging from a high of $83.3 \% \pm 16.7 \%$ on $T$. caroliniana to a low of $25 \% \pm 16.4 \%$ on T. heterophylla. T. canadensis was at the higher end of this range $(73.3 \% \pm 8.2 \%)$, whereas T. chinensis was at the lower end $(35.3 \% \pm 12 \%)$. On T. canadensis, the presence of elongate hemlock scale was strongly associated with the presence of hemlock woolly adelgid; there were no scales on $T$. canadensis that were free of adelgid, whereas $81 \%$ of the trees that had adelgids were also infested with scale 


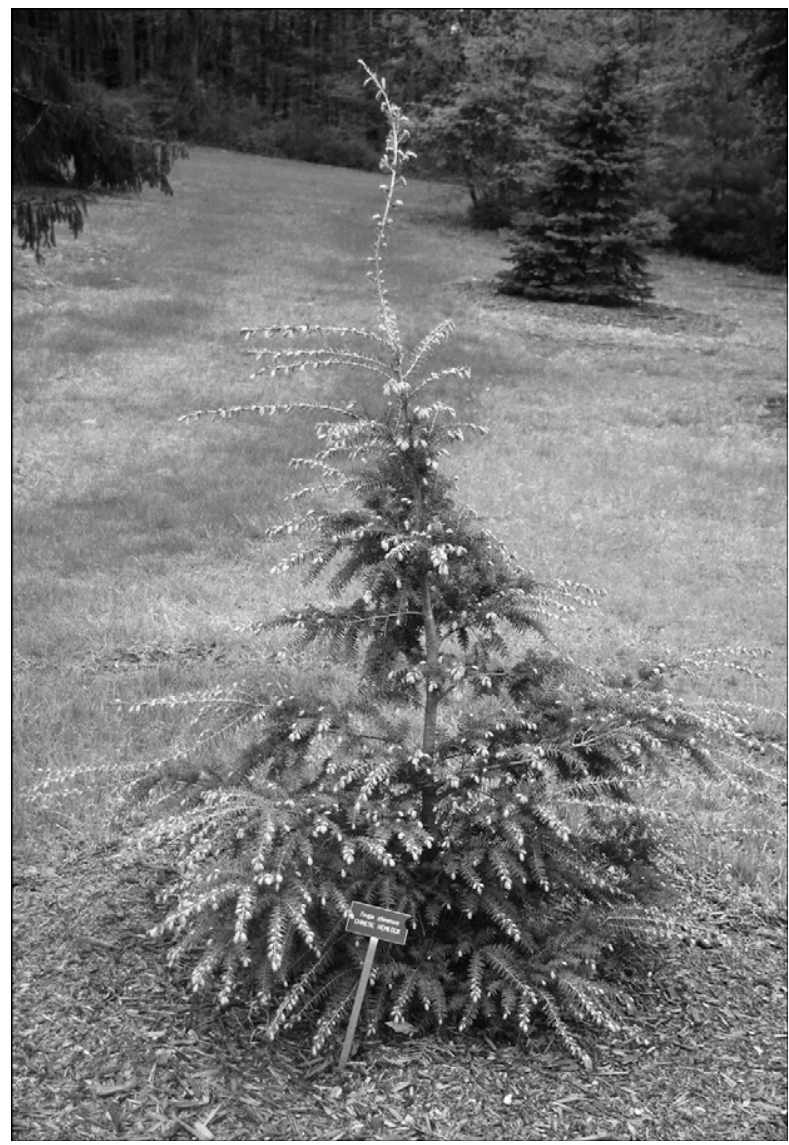

Figure 3. Photograph of Tsuga chinensis.

$\left(\chi^{2}=8.92, P=0.0028\right)$. There was no association between the two insects on the other test species.

Overall arthropod abundance on the test trees was low; most trees had none present at any of the sampling times. The most frequently encountered arthropods were spiders $(n=121)$, earwigs $(n=34)$, fungus gnats $(n=15)$, and robber flies $(n=11)$. Of these, only spiders would be expected to possibly feed on adelgids (although robber flies are predaceous, they prey on flying insects). Regression analysis revealed that spiders (or their webs) were most common on $T$. chinensis; significantly fewer were found on T. canadensis, and still fewer were found on the remaining species, which were not statistically different from each other (overall ANOVA $F=9.78 ; P<0.0001 ; \mathrm{df}=6,128$ ). It seems that tree size may have been more important than prey in determining the abundance of spiders because $T$. canadensis and $T$. chinensis were by far the largest trees. Other factors likely influence spider abundance, however, because their abundance was higher on T. chinensis despite that fact that these trees were considerably smaller than T. canadensis (Table 2). The presence of spiders on T. chinensis does not likely explain the absence of adelgids on this species because spiders are not known to prey on adelgids (Wallace and Hain 2002).

The results point strongly toward $T$. chenensis as a possible replacement for T. canadensis in the northeastern United States, if not beyond. Tsuga chinensis was most similar in our study to T. canadensis in terms of growth and vigor and appeared to be virtually immune to hemlock woolly adelgid based on our findings and those of others (Bentz et al. 2002; Del Tredici and Kitajima
2004; Havill and Montgomery 2008). The form of T. chinensis is also quite similar to T. canadensis, although the branches of T. chinensis tend to "weep" more than those of T. canadensis, and the needles are larger, generally darker and more lustrous, and more sparsely arrayed on the branches (pers. obs.) (Figure 3). It remains to be seen how large of a geographic area in the United States possesses a suitable climate for growth of $T$. chinensis. The species is more closely related to $T$. caroliniana than to T. canadensis (a more northerly species) based on results of breeding experiments (Bentz et al. 2002), yet still apparently thrived in the Hudson Valley of New York State, suggesting that it might be more broadly adapted to the climate in the United States.

Acknowledgments. Funding for establishment of the trees and initial data collection came from the NYS Integrated Pest Management program, and funding for continued data collection came from the U.S. Forest Service. Assistance for data collection over the duration of the project was provided by Jerry Giordano, Lora Schwartzberg, Betsy Lamb, and Gaylord Desurmont. Special thanks go to Ted Kozlowski, his crew, and the Westchester County Parks for providing space at Lasdon Park and Arboretum for the plots and access to equipment and mulch for maintaining the plots.

\section{LITERATURE CITED}

Bentz, S.E., L.G.H. Riedel, M.R. Pooler, and A.M. Townsend. 2002. Hybridization and self-compatibility in controlled pollinations of eastern North American and Asian hemlock (Tsuga) species. Journal of Arboriculture 28:200-205.

Del Tredici, P., and A. Kitajima. 2004. Introduction and cultivation of Chinese hemock (Tsuga chinensis) and its resistance to hemlock woolly adelgid (Adelges tsugae). Journal of Arboriculture 30:282-287.

Gouger, R.J. 1971. Control of Adelges tsugae on hemlock in Pennsylvania. Scientific Tree Topics 3:1-9.

Havill, N.P., and M.E. Montgomery. 2008. The role of arboreta in studying the evolution of host resistance to the hemlock woolly adelgid. Arnoldia 65:2-9.

McClure, M.S. 1991. Nitrogen fertilization of hemlock increases susceptibility to hemlock woolly adelgid. Journal of Arboriculture 17:227-229. . 1992. Hemlock woolly adelgid. American Nurseryman 175:82-89.

Rose, M.A., and E. Smith. 1996. Fertilizing Landscape Plants. Ohio State University Factsheet HYG 1002-96.

Wallace, M.S., and F.P. Hain. 2002. Summary of native and established predators of the hemlock woolly adelgid and the balsam woolly adelgid (Homoptera: Adelgidae) in the southeastern United States, pp. 141-149. In: Onken, B., R. Reardon, and J. Lashomb (Eds.). Proceedings, Symposium: Hemlock Woolly Adelgid in the Eastern U.S., 5-7 February, 2002, East Brunswick, NJ. USDA Forest Service.

Ward, J.S., M.E. Montgomery, C.A.S.-J. Cheah, B. Onken, and R.S. Cowles. 2004. Eastern Hemlock Forests: Guidelines to Minimize the Impacts of Hemlock Woolly Agelgid. USDA Forest Service, Morgantown, WV.

Paul A. Weston (corresponding author)

Department of Entomology

Cornell University

Ithaca, NY 14853, U.S.

paulweston23@gmail.com; paw23@cornell.edu

Richard W. Harper

Cornell Cooperative Extension of Westchester County

Valhalla, NY 10595, U.S. 
Résumé. La cochenille laineuse de la pruche (Adelges tsugae) a eu un impact dévastateur sur Tsuga canadensis et T. caroliniana dans les forêts et les aménagements paysagers de l'Est des ÉtatsUnis. Des espèces de Tsuga de l'Ouest des États-Unis et de l'Asie sont reportées comme tolérantes ou résistantes à A. adelges. Nous avons établi des parcelles d'essais contenant des $T$. canadensis, T. caroliniana, T. chinensis, T. diversifolia, T. heterophylla, T. mertensiana et T. sieboldii à Katonah dans l'état de New York, un secteur avec d'importantes populations de A. Tsugae, et nous avons suivi la croissance des arbres et l'infestation par la cochenille laineuse de la pruche durant quatre ans. La susceptibilité à la cochenille laineuse de la pruche variait aussi beaucoup entre les espèces: certaines espèces (particulièrement $T$. canadensis) devenaient rapidement infestées alors que d'autres (ex.: T. chinensis) étaient apparemment entièrement résistantes. En raison de la capacité de $T$. chinensis à composer avec le climat du Sud-est de New York et de son apparente résistance à la cochenille laineuse de la pruche, cette espèce pourrait être un choix approprié de remplacement, notamment au sein des aménagements paysagers.

Zusammenfassung. Die Hemlock-Wollschildlaus hat einen furchtbaren Einbruch bei den Beständen von Tsuga canadensis und $T$. caroliniana in den Wäldern und landschaftlich gestalteten Räumen der östlichen Vereinigten Staaten verursacht. Die Tsuga-Unterarten in den westlichen USA und Asien sind entweder tolerant oder resistent gegenüber der Wollschildlaus. Wir pflanzten Gruppen mit T. canadensis, T. caroliniana, T. chinensis, T. diversifolia, T. heterophylla, T. mertensiana, und T. sieboldii in Katonah, New York, U.S., einer Region mit hohem Populationsanteil von Wollschildläusen, und beobachteten über einen Zeitraum von 4 Jahren das Wachstum und den Befall mit Läusen. Das Wachstum und Überleben der Hemlock-Arten variierte stark, die besonders widerstandsfähigen Species sind T. canadensis und T. chinensis. Die Anfälligkeit gegenüber dem Insekt variierte ebenfalls stark unter den Species. Einige Species (besonders T. canadensis) wurden schnell infiziert, während andere (z. B. T. chinensis) völlig resistent waren. Bei der bestehenden Fähigkeit von T. chinensis zur erfolgreichen Anpassung an die klimatischen Bedingungen in den südöstlichen Teil vom Bundesstaat New York und ihrer offensichtlichen Resistenz gegenüber der Hemlock-Wollschildlaus, sollte diese Species als Ersatzpflanzung, besonders in landschaftlich gestalteten Räumen in Betracht gezogen werden.

Resumen. El aldegido (Adelges tsugae) ha tenido un impacto devastador en Tsuga canadensis y T. caroliniana en bosques y paisajes manejados en el este de los Estados Unidos. Las especies de Tsuga del oeste de los Estados Unidos y Asia están reportadas como tolerantes o resistentes a A. tsugae. Establecimos parcelas con T. canadensis, T. caroliniana, T. chinensis, T. diversifolia, T. heterophylla, T. mertensiana, y T. sieboldii en Katonah, New York, U.S., un área con altas poblaciones de A. tsugae, y monitoreamos el crecimiento de los árboles y la infestación por aldégidos en un período de 4 años. El crecimiento y supervivencia de las especies de Tsuga varió ampliamente, siendo las especies más vigorosas $T$. canadensis y $T$. chinensis. La susceptibilidad al aldégido también varió ampliamente entre especies; algunas especies (particularmente T. canadensis) se infestó rápidamente, mientras que otras (por ejemplo, T. chinensis) aparentemente fueron enteramente resistentes. Dada la habilidad de T. chinensis a crecer bien en el clima del sureste del Estado de New York y su resistencia aparente al aldégido, esta especie puede ser apropiada para el remplazo de especies, especialmente en paisajes bien manejados. 